УДК 544.77; 538.958

\title{
Optical Absorption Evolution of Silver Nanocomposites with Arabinogalactan-g-Oligopyrrole Copolymer Matrix
}

\author{
Anna V. Zhmurova* \\ Irkutsk State University of Railways, \\ Chernyshevskogo 15, Irkutsk, 664074, Russia \\ Leo E. Zelenkov ${ }^{\dagger}$, Boris G. Sukhov $\ddagger$ \\ A. E. Favorsky Irkutsk Institute of Chemistry SB RAS \\ Favorsky 1, Irkutsk, 664033, Russia \\ Anatoliy I. Illarionov ${ }^{\S}$ \\ Irkutsk National Research Technical University, \\ Lermontova 83, Irkutsk, 664074, Russia \\ Roman Y.Shendrik", Evgeniy A.Radzhabov \\ A. P. Vinogradov Institute of Geochemistry, SB RAS, \\ Favorsky 1a, Irkutsk, 664033, Russia \\ Igor V. Klimenkov" \\ Limnological Institute, SB RAS, \\ Ulan-Batorskaya 3, Irkutsk, 664033, Russia \\ Anatoliy N. Sapozhnikov, Boris A. Trofimov \\ A. P. Vinogradov Institute of Geochemistry, SB RAS, \\ Favorsky 1a, Irkutsk, 664033,Russia
}

Received 30.10.2016, received in revised form 13.06.2017, accepted 06.08.2017

The optical absorption spectra measured of radically new nanocomposite of silver nanoparticles and arabinogalactan-g-oligopyrrole block-copolymer have 3 optical bands at 294, 426 and $585 \mathrm{~nm}$. There have been no absorption maxima shifts but only absorption intensity decrease of the first and the second optical bands during eight months. Reduction of optical absorption intensity at $294 \mathrm{~nm}$ is related to decrease of acyl radical quantity in the nanocomposite. Decrease of $O D$ and $1 D$ nanosilver plasmon absorption intensity at $426 \mathrm{~nm}$ can be explained by increase of the nanoparticle size in consequent to nanoparticle coalescence. Optical absorption of nanocomposite at $585 \mathrm{~nm}$ is associated with longitudal component of $1 D$ nanosilver plasmon resonance and presence of plasmons in the oligopyrrole chains.

Keywords: optical absorption, metallopolymer nanocomposites, arabinogalactan, oligopyrrole, silver nanoparticles.

DOI: $10.17516 / 1997-1397-2018-11-1-60-65$.

\footnotetext{
*2zhannazh2@gmail.com

†zelleo@irioch.irk.ru

¥sukhov@irioch.irk.ru

\$illarionov.an1952@mail.ru

ฯ romus@igc.irk.ru

" iklimen@mail.ru

(C) Siberian Federal University. All rights reserved
} 


\section{Introduction}

One of the important directions in condensed matter physics is physical properties investigation of disordered systems, in particular one of conducting polymers, their copolymers and melts with other polymers as well as their nanocomposites with inorganic nanoparticles. Polypyrrole (PPy) is well studied representative of conducting polymers. It attracts attention due to relative simplicity of its synthesis, low cost of monomers, high conductivity, and good biocompatibility. However, it possesses also some disadvantages such as insolubility, inflexibility, poor mechanical strength. Several attempts to improve PPy properties are known. This problem may be solved by creating of polymer melts of conducting polymers and polymers that have potentially more promising properties $[1,2]$ or by synthesizing their copolymers [3-7]. Nowadays the search for the synthetic routes to such systems as nanocomposites with metallic nanoparticles dispersed in copolymer matrix [8] and study of their optical properties represent urgent challenge. The optical absorption investigation of silver nanocomposites based on arabinogalactan-g-oligopyrrole block-copolymer matrix and, in particular, the time dependence research of their absorption spectra are associated with prospects for the synthesis of metallopolymer nanocomposites with stable optical properties.

\section{Experimental}

In this paper we have investigated optical absorption of powders of silver nanocomposite with arabinogalactan-g-oligopyrrole block-copolymer matrix, pure arabinogalactan (AG), and pure PPy that was synthesized by oxidative polymerization of pyrrole with trivalent Fe cations in the presence of water.

Silver nanocomposite were synthesized in two stages as follows: (1) AG macromolecules were functionalized with tetrahydroindole "anchor" groups; (2) such group has one pyrrole fragment in its structure that enables to join PPy branch on the group by oxidative polymerization of addable pyrrole with silver cations. As a result, we have obtained a new nanocomposite that represents nanoparticles of zero-valent silver in arabinogalactan-g-oligopyrrole block-copolymer matrix. The percentage of silver in the nanocomposite is $8.9 \%$.

The optical absorption spectra of the samples were measured on Perkin Elmer LAMBDA 950 UV-Vis spectrophotometer (USA) using the $150 \mathrm{~mm}$ integrating sphere. Nanoparticle shape, average size and size distribution were obtained from images analysis. The measurements were done on Carl Zeiss LEO 906E transmission electron microscope (Germany) at accelerating voltage of $80 \mathrm{kV}$ using MegaView II camera. The crystal phase and average size of nanoparticles in the nanocomposite were investigated using Bruker D8 ADVANCE X-ray powder diffractometer (Germany).

\section{Results and discussion}

TEM images (Fig. 1) of synthesized silver nanocomposite with arabinogalactan-g-oligopyrrole block-copolymer matrix show that percentage of spherical nanoparticles (0D NPs) is $73 \%$ and remaining nanoparticles have ellipsoid shape (1D NPs). The 0D NPs mean diameter is $21.3 \mathrm{~nm}$. The 1D NPs longitudal size is $28.7 \mathrm{~nm}$ and transversal one is $20.9 \mathrm{~nm}$. These data are in accordance with the mean size of silver nanoparticles that was obtained by X-ray phase analysis $(17 \mathrm{~nm})$. 


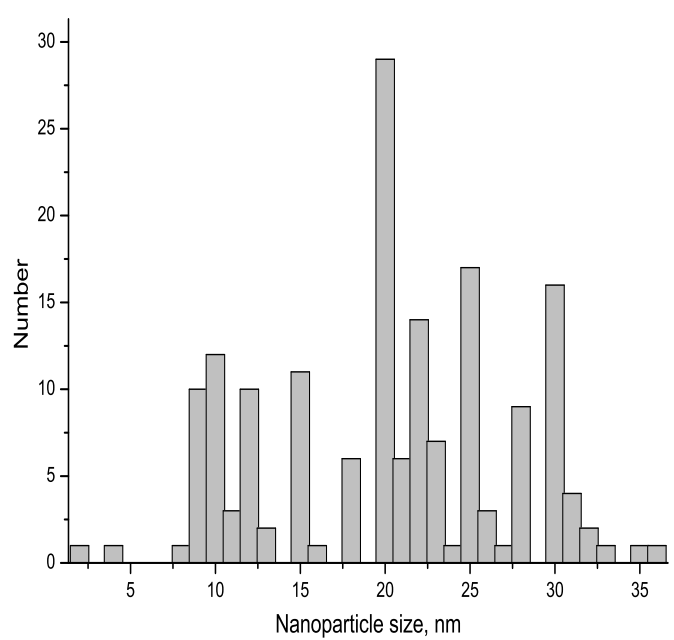

(a)

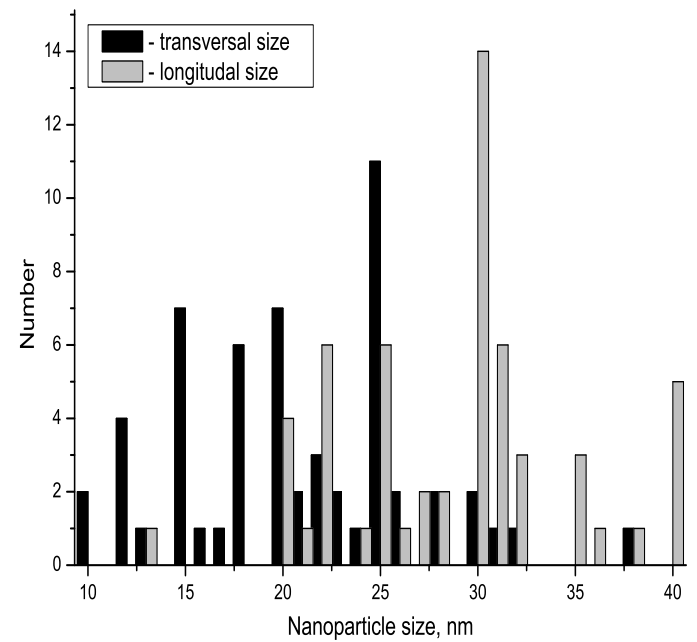

(b)

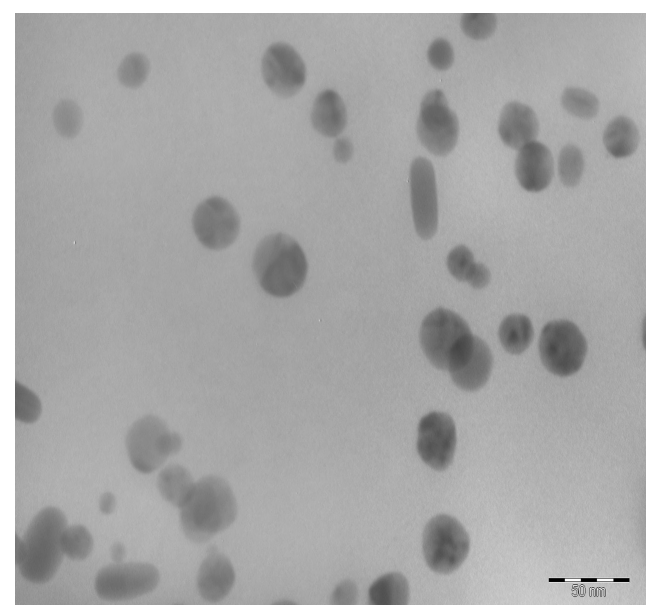

(c)

Fig. 1. TEM measurements data: (a) 0D NPs size distribution histogram, (b) 1D NPs size distribution histogram and (c) nanocomposite TEM image

We have measured optical absorption spectra of nanocomposite over a wavelength range from 250 to $800 \mathrm{~nm}$ four times during eight months: the first measurement then one month, four and eight months later (Fig. 2).

Fig.2. (curves 1-4) shows that absorption bands at $294 \mathrm{~nm}, 426 \mathrm{~nm}$ and $585 \mathrm{~nm}$ are inherent to optical absorption spectra of silver nanocomposite. Absorption maximum at $294 \mathrm{~nm}$ can be explained by the presence of AG in the nanocomposite matrix. Absorption band of AG powder is observed at $282 \mathrm{~nm}$ (Fig. 2, curve 5) that corresponds to $n \rightarrow \pi^{*}$ forbidden transitions of polysaccharide end aldehyde groups [9,10]. AG absorption peak is by $12 \mathrm{~nm}$ red-shifted, observed after the silver nanocomposite synthesis, can be due to the formation of free radicals [11], in particular, acyl ones from polysaccharide aldehyde groups under redox synthesis. Nanocomposite absorption band at $426 \mathrm{~nm}$ is related to Localized Surface Plasmon Resonance (LSPR) in silver 0D NPs and transversal component of 1D NPs LSPR [12]. The third absorption maximum of nanocomposite at $585 \mathrm{~nm}$ is a consequence of longitudal component of 1D NPs LSPR and optical absorption of polarons in oligopyrrole branches [3]. Optical absorption band of pure 


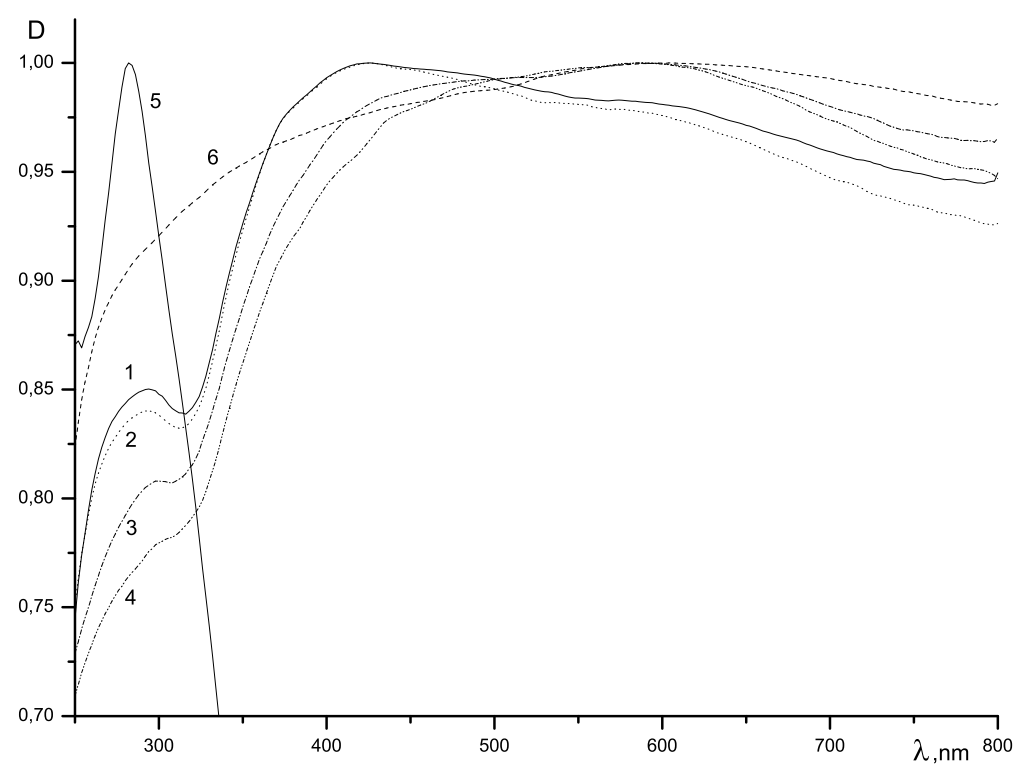

Fig. 2. Normalized optical absorption spectra of samples: 1 - silver nanocomposite with arabinogalactan-g-polypyrrole block-copolymer matrix, 2 - silver nanocomposite month later, 3 - four months later, 4 - eight months later, 5 - arabinogalactan, 6 - polypyrrole

polypyrrole is observed at $600 \mathrm{~nm}$ (Fig. 1, curve 6). It is known that absorption maximum at $390 \mathrm{~nm}$ is inherent for films of undoped polypyrrole [13,14], and absorption spectra of weakly doped polypyrrole have three optical absorption bands at about $594 \mathrm{~nm}$ (electron transition from HOMO to upper polaron level), $891 \mathrm{~nm}$ (electron transition from lower to upper polaron level) and $1781 \mathrm{~nm}$ (electron transition from HOMO to lower polaron level) [14]. The presence of absorption band at $500 \mathrm{~nm}$ and broad absorption peak from 700 to $2000 \mathrm{~nm}$ in optical absorption spectra of doped polypyrrole is reported in [13]. The absorption maximum in the NIR region corresponds to the polaron and bipolaron energy levels (as it is pointed in [13]). On the basis of the above, we associate absorption peak at $600 \mathrm{~nm}$ in optical absorption spectrum of pure polypyrrole with the existence of polarons and biopolarons in polypyrrole chains that pass into weakly doped state under influence of environment air.

As time passes, curve shape of silver nanocomposite optical absorption spectrum has changed. The curve shape has not essentially changed for a month after the first measurement. However, intensity decrease of optical absorption at 294 and $426 \mathrm{~nm}$ has become notable four months later, while absorption peak at $585 \mathrm{~nm}$ has revealed itself more prominent. This appears more evident eight months after. The intensity reduction of the first absorption maximum may be attributed to quantitative loss of high reactive acyl radicals as a consequence of their continued transformations. The decrease of plasmonic absorption intensity at $426 \mathrm{~nm}$, which takes place during the time, may be related to integration of silver nanoparticles on account of their coalescence and formation of the strongly coupled metal nanostructures [12], which have a long wave absorption dependent on the size of new elongated nanostructures. Broadened character of peak at $585 \mathrm{~nm}$ arises from wide fractional composition of nanostructures obtained and also is due to increased content of low doped oligopyrrole fragments (that is growth of polaron content). The latter is formed by doping of oligopyrrole fragments by air oxygen during storage. 


\section{Conclusion}

The presence of absorption bands at 294, 426, and $585 \mathrm{~nm}$ in optical absorption spectra is characteristic of fundamentally new silver nanocomposite with arabinogalactan-g-oligopyrrole block-copolymer matrix. With the course of time, there are no shifts of absorption peaks, and absorption intensity of the first and the second bands markedly drops. Absorption maximum of nanocomposite at $294 \mathrm{~nm}$ is a consequence of absorption red shift of end aldehyde groups (it can be observed at $282 \mathrm{~nm}$ for arabinogalactan powder) that can be explained by with their one-electron oxidation and formation of acyl radicals. The absorption intensity decrease at $294 \mathrm{~nm}$ can be accounted for by diminution in quantity of high reactive acyl radicals in nanocomposite during the time and as a result of their further transformations. The intensity decrease of the nanocomposite optical absorption at $426 \mathrm{~nm}$ produced by 0D NPs and 1D NPs plasmon resonance may be related to agglomeration of the nanoparticles as a consequence of their coalescence. Nanocomposite absorption band at $585 \mathrm{~nm}$ may be explained by overvapping signals of longitudal component of 1D NPs LSPR and polarons of oligopyrrole chains that are grafted to arabinogalactan.

This work was done using the equipment of Baikal Analytical Center of Common Use, "Ultramicroanalysis" Collective Instrumental Center and "Isotopic and geochemical investigations" Center of Common Use and with financial support of NIR V.46.4.1. state task (number of state registration is 01201281990)

\section{References}

[1] Y.N.Kupriyanovich, et al., New method of polypyrrole synthesis with enzyme catalysis of radical polymerization, Organic Chemistry from Butlerov and Beyl'shteyn to the present, Int. conf. on Organic Chemistry devoted to 145th anniversary of A.M. Butlerov structure theory of organic compounds and centenary of F.F. Beyl'shteyn memoral day, book of abstracts, St. Petersburg, St. Petersburg University Press, 2006, 754-755 (in Russian).

[2] Y.N. Kupriyanovich, B.G. Sukhov, S.A. Medvedeva, et al., Peroxidase-catalysed synthesis of electroconductive polypyrrole, Mendeleev Communications, 18(2008), no 1, 56-58.

[3] M.Cabuk et al. , Synthesis, characterization and antimicrobial activity of biodegradable conducting polypyrrole-graft-chitosan copolymer, Appl. Sur. Sci., 318(2014), 168-175.

[4] E.N.Zare, M.M.Lakouraj, M.Mohseni, Biodegradable polypyrrole / dextrin conductive nanocomposite: synthesis, characterization, antioxidant and antibacterial activity, Synth. Met., 187(2014), 9-16.

[5] E.A. Guvel, N. Kizilcan, Polypyrrole-vinyl aniline modified cyclohexanone formaldehyde resin copolymers: a comparative study of the resin preparation, J.Appl. Polym Sci., 42841(2015), $1-9$.

[6] Y.N. Kupriyanovich et al., Hybrid polysaccharide-conducting polypyrrole structures, In: E.F. Martynovich (Ed.), XII International school-seminar on luminescence and laser physics, book of abstracts, Khuzhir, Irkutsk, ISU Press, 2010, 130-131 (in Russian).

[7] A.V.Zhmurova et al., Optical absorption of silver nanoparticles dispersed in polypyrrolearabinogalactan grafted copolymer, In: E.F.Martynovich (Ed.), XV International conference 
on luminescence and laser physics, book of abstracts, Irkutsk, ISU Press, 2016, 73 (in Russian).

[8] I.G.Peretyat'ko, L.E.Zelenkov, B.G.Sukhov, New "polysaccharide - high polyconjugated chain" hyperbranched block-copolymers of assigned morphology and ones-based hybrid nanocomposites, In: D.A.Shabalin, O.V. leshkova (Eds.), Theoretical and experimental chemistry in young eyes, book of abstracts of All-Russian scientific conference devoted to eightieth anniversary of ISU Chemical department, Irkutsk, ISU Press, 2013, 126-127 (in Russian).

[9] M.Z.Gavrilov, I.N.Ermolenko, Investigation of dialdehyde cellulose electronic spectra, Polymer Science Series A, IX(1967), no. 8, 1688-1692.

[10] C.N.R.Rao, Ultra-violet and visible spectroscopy, chemical applications, Moscow, Mir, 1964 (in Russian).

[11] E.Ya.Davydov, G.B.Pariyskiy, D.Ya.Toptygin, Concerning the phototransformations of PMMA ester groups free radicals, Polymer Science Series A, XVII(1975), no. 2, 1504-1509 (in Russian).

[12] N.J.Halas, S.Lai, W.-S. Chang, et al., Plasmons in Strongly Coupled Metallic Nanostructures, Chem. Rev., 111(2011), no. 6, 3913-3961.

[13] Y.Li, Conducting polymers, In: Y.Li (Ed.), Organic Optoelectronic Materials, Lecture Notes in Chemistry 91, London, Springer, 2015, 23-50.

[14] P.Galar, B.Dzurnak, P.Maly et al., Chemical changes and photoluminescence properties of UV Modified polypyrrole, Int. J. Electrochem. Sci., 8(2013), 57-70.

\section{Эволюция оптического поглощения нанокомпозитов серебра с сополимерной матрицей арабиногалактан-олигопиррол}

Анна В. Жмурова

Иркутский государственный университет путей сообщения

Чернышевского, 15, Иркутск, 664074, Россия

Лев Е. Зеленков, Борис Г. Сухов, Анатолий И. Илларионов, Роман Ю. Шендрик, Евгений А. Раджабов, Игорь В. Клименков, Анатолий Н. Сапожников, Борис А. Трофимов

\footnotetext{
B спектрах оптического поглощения приниипиально нового нанокомпозита серебра с привитым блок-сополимером арабиногалактан-олигопиррол, для которого характерны полосы поглощения при 294, 426, 585 нм, в течение восъми месяцев наблюдали снижение интенсивности поглощения первых двух максимумов поглощения. Убывание интенсивности при 294 нм обълсняется уменьшением количества ацильных радикалов, возникающих в арабиногалактане при синтезе нанокомпозита. Снижение интенсивности плазмонного поглощения при 426 нм 0D- u $1 D$ наносеребра, возможно, связано с укрупнением частич за счет их коалесцениии. Оптическое поглощение нанокомпозита при 585 нм обусловлено продольной компонентой плазмонного резонанса $1 D$-наносеребра и наличием поляронов в олигопирролъных ветвях.
}

Ключевые слова: оптическое поглощение, металлополимерные нанокомпозиты, арабиногалактан, олигопиррол, наночастицы серебра. 